\title{
Electroconvulsive therapy use in adolescents: a systematic review
}

\author{
Nádia NR Lima', Vânia B Nascimento ${ }^{1}$, Jorge AC Peixoto ${ }^{1}$, Marcial M Moreira' ${ }^{1}$, Modesto LR Neto ${ }^{2 *}$, \\ José C Almeida ${ }^{3}$, Carlos AC Vasconcelos ${ }^{4}$, Saulo A Teixeira ${ }^{5}$, Jucier G Júnior ${ }^{5}$, Francisco TC Junior ${ }^{5}$, \\ Diego DM Guimarães ${ }^{5}$, Aline Q Brasil ${ }^{5}$, Jesus S Cartaxo ${ }^{1}$, Marco Akerman ${ }^{1}$ and Alberto OA Reis ${ }^{6}$
}

\begin{abstract}
Background: Considered as a moment of psychological vulnerability, adolescence is remarkably a risky period for the development of psychopathologies, when the choice of the correct therapeutic approach is crucial for achieving remission. One of the researched therapies in this case is electroconvulsive therapy (ECT). The present study reviews the recent and classical aspects regarding ECT use in adolescents.

Methods: Systematic review, performed in November 2012, conformed to the PRISMA statement.

Results: From the 212 retrieved articles, only 39 were included in the final sample. The reviewed studies bring indications of ECT use in adolescents, evaluate the efficiency of this therapy regarding remission, and explore the potential risks and complications of the procedure.

Conclusions: ECT use in adolescents is considered a highly efficient option for treating several psychiatric disorders, achieving high remission rates, and presenting few and relatively benign adverse effects. Risks can be mitigated by the correct use of the technique and are considered minimal when compared to the efficiency of ECT in treating psychopathologies.
\end{abstract}

\section{Background}

Adolescence is a period of deep emotional and physical changes. This moment of psychological vulnerability favors the development of serious and potentially damaging psychopathologies [1]. Adolescents present higher rates of self-destruction impulses and are more commonly refractory to traditional medications. In addition, major depression affects near $8 \%$ of adolescents, more commonly during puberty. Forty percent of them present recurrent attacks, and a third will experience at least one suicide attempt [2]. In these cases, the choice of the correct therapeutic modalities is crucial for achieving the remission of symptoms.

The introduction of electroconvulsive therapy (ECT) for the treatment of serious mental disturbs, such as major depression and bipolar disorder, was one of most impacting revolutions of psychiatry. Convulsive therapy

\footnotetext{
* Correspondence: modestorolim@hotmail.com

${ }^{2}$ Research Group CNPq/UFC: Information Technology, Communication, Narrativity, Society and Plural Identities, Federal University of Ceará (UFC), Juazeiro do Norte, Ceará 63.048-060, Brazil

Full list of author information is available at the end of the article
}

was introduced to psychiatric practice in 1934, by Hungarian neuropsychiatrist László Meduna [3]. In his autobiography [4], Meduna described L. Zoltán's case, his first patient subjected to convulsive therapy $[3,4]$. L. Zoltán had a 4-year condition of catatonic schizophrenia that was considered hopeless but after having received several sessions of camphor-induced convulsive therapy [4,5], achieved full remission [3]. Later on, in 1938, Bini and Cerletti reported the first electroconvulsive procedure, suggesting the use of electricity after observing the clinical success and difficulties of seizure inductions with metrazol [6].

Due to controversies regarding its effectiveness and safety, for a long time, ECT had a bad reputation and was considered untrustworthy. Only in the 1970s, the American Task Force Report on ECT proved the effectiveness of ECT use, especially in the depressed phase of bipolar disorder and the 'involutional melancholia' [7].

Brazilian Federal Council of Medicine, in its Resolution n. 1640, published in July 2002, regulates the use of electroconvulsive therapy in Brazil. Still, it prohibited 
the use of ECT in patients below 16 years of age, unless in exceptional circumstances [8].

Along these lines, a key question addressed by this study is whether ECT is useful for therapeutic purposes in adolescents. Taking this into consideration, this study aimed at reviewing the recent and classical aspects regarding electroconvulsive therapy and its application for adolescents; we performed a detailed, systematic review of medical literature, of which resulted in this article.

\section{Methods}

We performed, in November 2012, a qualitative systematic review of articles about the role of electroconvulsive therapy use in adolescents published in previously chosen electronic databases. The qualitative approach was chosen because quantitative methods, such as metaanalysis, show that (a) the necessary information in order to calculate result size is not available and may limit this analysis to a small subset of studies and (b) age intervals regarding adolescence vary greatly among studies included in the sample, making it difficult to adequately compare and to do the proper statistical analysis.

The methods used to identify, select and appraise relevant research, and to collect and analyze data from the studies we reviewed were in agreement with the PRISMA protocol for systematic reviews and metaanalyses [9]. According to The Cochrane Collaboration, which published the PRISMA guidelines, reporting medical research in systematic reviews must be based in information that composes the acronym 'PICOS' (patient, intervention, comparator, outcome, study design). For this article, 'P' represented adolescents, 'I' was electroconvulsive therapy, ' $\mathrm{C}$ ' was absent or only-pharmacological therapy, 'O' was symptoms remission and ' $\mathrm{S}$ ' was case reports, series of cases, literature reviews, cross-sectional studies, exploratory field research and prospective/retrospective cohorts.

In order to set a parameter for limiting the age group covered by the present review, the definition of 'adolescence' adopted in this study was from Medical Subject Headings $\mathrm{MeSH}$ ), the National Library of Medicine's controlled vocabulary thesaurus used for indexing articles for PubMed. Thus, when used in this study, the term 'adolescent' refers to a person from 13 to 18 years of age and consequently, the term 'adolescence' refers to the state or time of being 13 to 18 years of age.

Then, each paper in the sample was read entirely, and data elements were then extracted and entered into a matrix that included authors, publication year, description of the study sample and main findings, as well as a matrix that included the PICOS acronym of the selected articles. Some of the studies dealt not only with ECT use in adolescents but also in children and adults; because the focus of this study was on ECT use in adolescents, children- or adult-related results were not recorded or analyzed for this study.

Finally, so as to provide a better analysis, the next phase involved grouping, for heuristic reasons, results regarding the studied subject in four themes: (1) indications for ECT use in adolescents; (2) electroconvulsive therapy - treatment parameters; (3) efficiency of ECT, associations with other therapies and comparison between techniques; and (4) side effects, risks, and complications of ECT for adolescents.

\section{Literature review}

Three medical databases were surveyed: PMC (United States National Library of Medicine), LILACS (Literatura Latino-Americana e do Caribe em Ciências da Saúde), and SciELO (Scientific Electronic Library Online). The keywords used in all searches were all valid $\mathrm{MeSH}$ (NLM/NIH) terms: 'electroconvulsive therapy', 'electroshock, 'ECT, 'adolescence,' 'adolescent,' 'treatment,' 'depression,' 'schizophrenia', and 'bipolar disorder'.

\section{Eligibility criteria}

Selected articles were according to the following inclusion criteria: (1) manuscripts written in English, Portuguese, Spanish, or French; (2) case reports, series of cases, case-controls, literature reviews, cross-sectional studies, exploratory field research, and prospective and retrospective cohort studies; (3) studies regarding the use of electroconvulsive therapy in adolescents, provided they attended at least three of the five previously mentioned PICOS criteria: adolescent, ECT, absent or only drugs, symptoms remission, and study design. Studies assessing other conditions, editorials, and letters to the editor were excluded.

\section{Results}

Initially, the aforementioned search strategies resulted in 212 references. After assessing the title and abstract of the retrieved citations for eligibility based on the inclusion criteria, 139 articles were excluded after applying criteria 1 and 2, and 40 manuscripts were excluded after applying criterion 3 .

At this moment, six additional articles were included in the sample $[2-5,9,10]$, identified through the reference lists of the previously retrieved articles and considering their importance to the field of study. Finally, 39 articles were further selected and included in the final sample (Figure 1).

Table 1 provides an overview of all studies included in the final sample, synthesizing the studies' characteristics, with reference to participants, interventions, comparisons, outcomes, and study design (PICOS), according to PRISMA statement. 


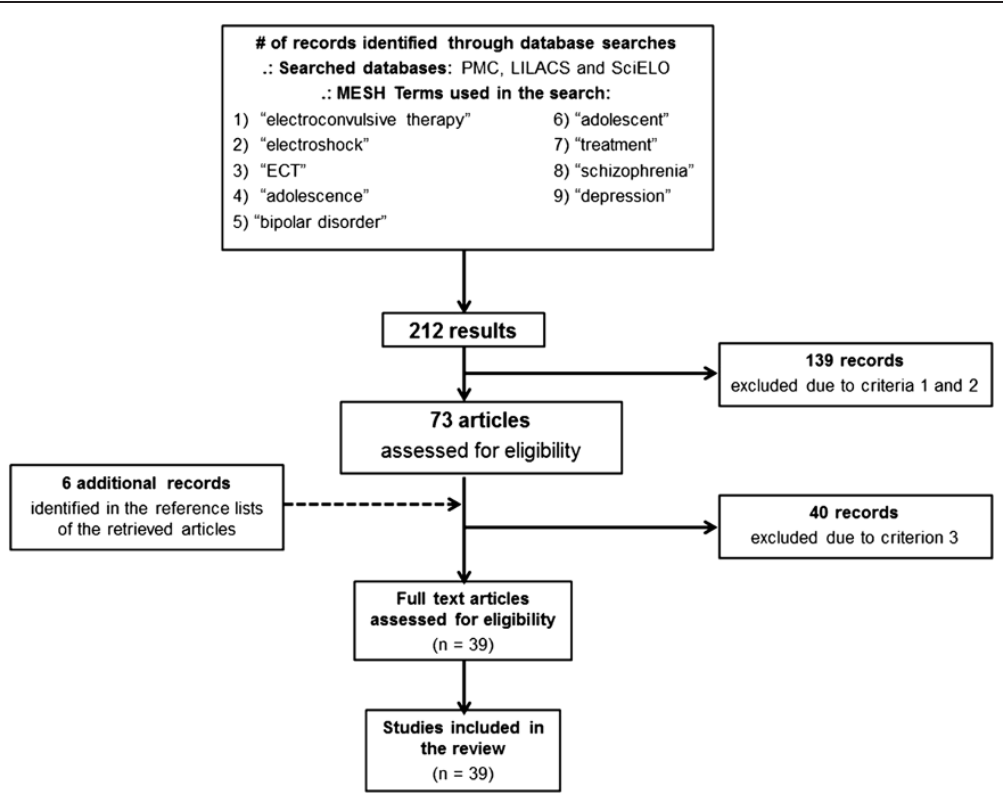

Figure 1 Flow chart showing study selection for the review.

\section{Discussion}

The present study reviewed 39 articles that dealt with different aspects of the use of ECT and its application in adolescents. Table 2 summarizes the main findings regarding the use of ECT in adolescents, grouped in three different sections. We now proceed to analyze the main findings of the retrieved studies.

\section{Indications for ECT use in adolescents}

Although information on the subject is scarce [29], indications for ECT use in adolescents cover a wide range of psychological diseases. The American Academy of Child and Adolescent Psychiatry (AACAP) has issued a guideline titled 'Practice Parameter For Use of Electroconvulsive Therapy With Adolescents,' establishing that eligibility for ECT in adolescents involves meeting three criteria, as follows: (1) diagnosis, (2) severity of symptoms, and (3) lack of treatment response to appropriate psychopharmacological agents accompanied by other appropriate treatment modalities [27]. Regarding diagnosis, ECT use is recommended for adolescents with serious psychiatric disorders, such as persistent major depression, schizoaffective disorder, schizophrenia, or history of manic episodes, with or without psychotic features [19]. Other studies point out that ECT can be used in this population also to treat catatonia and neuroleptic malignant syndrome $[26,30]$. Still according to AACAP's guideline, patient's symptoms must be severe, persistent, and significantly disabling, what can include lifethreatening symptoms, such as refusal to drink or eat, uncontrollable mania, florid psychosis, and severe suicide intentions [27]. The lack of treatment response - when considered at least two adequate trials of correct drugs, in association with other therapeutic modalities is also one of the three criteria, and the fulfillment of this criterion may require patient's observation in a hospital setting [20].

Electroconvulsive therapy may be considered earlier in cases when psychopharmacological treatment is not tolerated by the patient, when adolescent is significantly incapacitated, not being able to take medication, or when waiting for response of psychopharmacological treatment may put the patient's life at risk $[17,27]$.

After conducting a thorough medical evaluation, the psychiatrist decides whether the patient is to be treated with ECT. The severity of illness must be evaluated with extra care by a detailed patient interview, as well as by gathering information from parents or caregivers and by the use of a reliable symptom assessment scale [38]. It is also important to know about previous pharmacological treatment (asking about drugs, dosage, duration, compliance, response, and side effects). In some cases, compliance rate evaluation requires measuring urine and serum drug levels. Psychotherapeutic approaches (individual, interpersonal, or cognitive-behavioral therapies) experienced by the patient should also be recorded in the patient's medical chart.

Despite being as effective in adolescents as it is in adults [29], ECT is much less frequently used in adolescents. Three of the retrieved studies compared ECT use in adolescents with ECT use in patients of other ages. Adolescents subjected to ECT accounted for only $0.43 \%$ of the total in India, $0.93 \%$ in Australia, and $1.5 \%$ in the USA $[32,33,36]$. 
Table 1 Characteristics (PICOS) of the articles included in the review

\begin{tabular}{|c|c|c|c|c|c|}
\hline $\begin{array}{c}\text { Author } \\
\text { (publication year) }\end{array}$ & Patient & Intervention & Comparator & Outcome & Study design \\
\hline Gedge et al. [11] (2012) & Age 18 or older & ECT and rTMS & Absent & $\begin{array}{l}\text { Serum BDNF may not be a } \\
\text { biomarker of ECT or rTMS } \\
\text { treatment response }\end{array}$ & Prospective cohort \\
\hline Garg et al. [12] (2011) & Age 16 to 65 & ECT & Absent & Yes & Prospective cohort \\
\hline $\begin{array}{l}\text { Rolim-neto et al. [2] } \\
\text { (2011) }\end{array}$ & $\begin{array}{l}\text { Children and } \\
\text { adolescents }\end{array}$ & - & Absent & Child depression & Literature review \\
\hline $\begin{array}{l}\text { Shoirah and Hamoda } \\
\text { [13] (2011) }\end{array}$ & Adolescents & ECT & Absent & - & Literature review \\
\hline Wachtel et al. [6] (2011) & $\begin{array}{l}\text { Children and } \\
\text { adolescents }\end{array}$ & ECT & Absent & Efficacy rate of $63 \%$ for depression & Literature review \\
\hline Baeza et al. [7] (2010) & Age 13 to 17 & $\begin{array}{l}\text { Evaluation before, } \\
\text { after and } 6 \text { months } \\
\text { after ECT }\end{array}$ & Absent & $\begin{array}{c}\text { ECT is safe and effective treatment } \\
\text { for SSD }\end{array}$ & $\begin{array}{l}\text { Retrospective } \\
\text { cohort }\end{array}$ \\
\hline Consoli et al. [14] (2010) & $\begin{array}{l}\text { Children and } \\
\text { adolescents }\end{array}$ & ECT & Absent & - & Literature review \\
\hline $\begin{array}{l}\text { Antunes et al. [15] } \\
\text { (2009) }\end{array}$ & - & ECT & Absent & 50 to $80 \%$ & Literature review \\
\hline Hazell [1] (2009) & $\begin{array}{l}\text { Children and } \\
\text { adolescents }\end{array}$ & Various & Absent & $\begin{array}{l}\text { No article about ECT met the } \\
\text { including criteria }\end{array}$ & Systematic review \\
\hline Moher et al. [9] (2009) & - & - & - & PRISMA statement & Review \\
\hline $\begin{array}{c}\text { Baghai and Moller } \\
\text { [16] (2008) }\end{array}$ & - & ECT & Absent & $\begin{array}{c}\text { ECT is treatment proven to be a } \\
\text { highly effective treatment } \\
\text { option depression }\end{array}$ & Literature review \\
\hline Feliu et al. [17] (2008) & Age 19 to 96 & ECT & Absent & Yes & Series of cases \\
\hline $\begin{array}{l}\text { Lévy-Rueff et al. [18] } \\
\text { (2008) }\end{array}$ & Age 30 to 67 & ECT & Absent & $\begin{array}{l}\text { Moderate efficacy of M-ECT on } \\
\text { schizophrenia }\end{array}$ & $\begin{array}{l}\text { Retrospective } \\
\text { cohort }\end{array}$ \\
\hline Arshad et al. [19] (2007) & Age 16 and above & $\begin{array}{l}\text { Questionnaire } \\
\text { about ECT }\end{array}$ & Absent & Low acceptability of ECT & $\begin{array}{l}\text { Cross-sectional } \\
\text { study }\end{array}$ \\
\hline Blaj et al. [20] (2007) & - & ECT & Absent & Questionnaire to psychiatrists & $\begin{array}{l}\text { Exploratory field } \\
\text { research }\end{array}$ \\
\hline Datka et al. [21] (2007) & - & ECT & Only drugs & $\begin{array}{l}\text { Only temporally affects working } \\
\text { memory function }\end{array}$ & Prospective cohort \\
\hline Prakash et al. [22] (2006) & Adults & ECT & Absent & Donepezil improves recovery time & $\begin{array}{l}\text { Triple blind } \\
\text { prospective cohort }\end{array}$ \\
\hline Salleh et al. [23] (2006) & - & ECT & Absent & $\begin{array}{l}\text { Efficacy and safety of ECT on } \\
\text { depression treatment }\end{array}$ & Literature review \\
\hline Stein et al. [24] (2006) & $\begin{array}{l}\text { Children and } \\
\text { adolescents }\end{array}$ & ECT & Absent & - & Literature review \\
\hline Zaw [25] (2006) & $\begin{array}{l}\text { Children and } \\
\text { adolescents }\end{array}$ & ECT & Absent & - & Literature review \\
\hline $\begin{array}{l}\text { Sienaert et al. [26] } \\
\text { (2005) }\end{array}$ & Adults and aged & ECT & Absent & $\begin{array}{l}\text { ECT patients have memory } \\
\text { complaints, but it is not related } \\
\text { to satisfaction with treatment }\end{array}$ & $\begin{array}{l}\text { Exploratory field } \\
\text { research }\end{array}$ \\
\hline $\begin{array}{l}\text { Ghaziuddin et al. } \\
\text { [27] (2004) }\end{array}$ & Adolescents & ECT & Absent & $\begin{array}{l}\text { Mood disorders have a high rate } \\
\text { of response ( } 75 \% \text { to } 100 \%)\end{array}$ & Literature review \\
\hline Segal et al. [28] (2004) & Age 13 & ECT & Absent & Full symptom resolution & Case report \\
\hline Bloch et al. [29] (2001) & Age 13 to 19 & ECT & Absent & $58 \%$ remission & $\begin{array}{l}\text { Retrospective } \\
\text { cohort }\end{array}$ \\
\hline Daly et al. [30] (2001) & $\begin{array}{l}\text { Average group } \\
\text { age of } 58.5 \text { and } \\
55.8 \text { years old }\end{array}$ & ECT & Absent & Yes & Prospective cohort \\
\hline Cohen et al. [31] (2000) & $\begin{array}{l}\text { Adolescents aged } \\
\text { less than } 19 \text { years old }\end{array}$ & ECT & Only drugs & $\begin{array}{l}\text { Cognitive functions similar to } \\
\text { non-ECT }\end{array}$ & $\begin{array}{l}\text { Retrospective } \\
\text { cohort }\end{array}$ \\
\hline
\end{tabular}


Table 1 Characteristics (PICOS) of the articles included in the review (Continued)

\begin{tabular}{|c|c|c|c|c|c|}
\hline $\begin{array}{l}\text { Ghaziuddin et al. } \\
\text { [32] (1999) }\end{array}$ & Age 16 & ECT & Absent & $\begin{array}{l}\text { Clinical improvement, but } \\
\text { no significant change in } \\
\text { depression score }\end{array}$ & Case report \\
\hline $\begin{array}{l}\text { Thuppal and Fink } \\
\text { [33] (1999) }\end{array}$ & Adolescents and adults & ECT & Absent & $\begin{array}{c}\text { ECT successful after } \\
\text { pharmacotherapy failure on } \\
\text { mental retardation }\end{array}$ & Series of cases \\
\hline $\begin{array}{c}\text { Kutcher and Robertson } \\
\text { [34] (1995) }\end{array}$ & Age 16 to 22 & ECT & Absent & Yes & Prospective cohort \\
\hline Calev [35] (1994) & - & ECT & - & Trends on ECT treatment & Literature review \\
\hline Parmar [36] (1993) & $\begin{array}{l}\text { Children and } \\
\text { adolescents, psychiatrists }\end{array}$ & ECT & Absent & $\begin{array}{l}\text { ECT was less useful in child and } \\
\text { adolescent psychotic depression }\end{array}$ & Questionnaire \\
\hline $\begin{array}{c}\text { Schneeklot et al. } \\
\text { [37] (1993) }\end{array}$ & Adolescents & ECT & Absent & $\begin{array}{l}\text { ECT reduced or eliminated } \\
\text { symptoms }\end{array}$ & $\begin{array}{c}\text { Retrospective case } \\
\text { review }\end{array}$ \\
\hline APA [38] (1990) & Various & ECT & Absent & Yes & Literature review \\
\hline $\begin{array}{l}\text { Paillère-Martinot et al. } \\
\text { [39] (1990) }\end{array}$ & Adolescents & ECT & Absent & Yes & Comparative study \\
\hline
\end{tabular}

\section{Electroconvulsive therapy treatment parameters}

According to the technique of choice, electroconvulsive therapy may alter its efficacy. The study of Antunes and colleagues [15] showed that high-dose unilateral ECT sessions have equivalent efficacy as bifrontotemporal ECT; on the other hand, low-dose unilateral ECT has lower efficacy. The same research also brings preliminary results of studies that suggest that right unilateral ECT with ultra-brief stimulation, achieved by modern ECT equipment, preserves the efficacy and substantially reduces the cognitive side effects.

Another study [27] states that the use of unilateral electrode placement applied to the non-dominant cerebral hemisphere (usually the right brain in most right-handed persons) is associated with less memory impairment in the immediate post-treatment period, recommending bilateral treatment only if unilateral treatment does not reach an adequate response.

Still regarding electrode placement, Shoira and Hamoda [13] state that although bilateral electrode placement may be more effective than unilateral placement for manic patients, unilateral electrode placement has been found to have equivalent results for other indications. However, higher stimulus doses are needed in unilateral treatment to achieve comparable efficiency. Unilateral stimulation at six times the seizure threshold was found to have a remission rate of $55 \%$, compared with $61 \%$ for bifrontal stimulation and to $64 \%$ for bitemporal stimulation at 1.5 times the seizure threshold. When employing ultra-brief stimulation with modern ECT equipment, unilateral electrode placement at six times the seizure threshold has even been reported to be more effective than bilateral placement at 1.5 times the seizure threshold.

Summing up, it can be speculated that the best technique of ECT is unilateral, over the non-dominant cerebral hemisphere, using modern equipment capable of brief or ultra-brief stimulation. A study with a quantitative approach, comparing the efficacy and side effects of unilateral and bilateral approaches, would be extremely helpful to patients and procedure guidance.

Baeza and colleagues [7], on a study with a sample of 13 adolescents, used the bifrontotemporal ECT until the acute symptoms remitted or no further improvement was shown over three consecutive sessions. Positive results appeared within $13.9 \pm 4.3$ ECT sessions, with a mean duration of electroencephalogram seizures of $43.9 \pm$ $16.9 \mathrm{~s}$ (range, 20 to 93), with significant differences between males and females. Baghai and Moller [16] state that the remission rate of psychotic depression approaches $90 \%$, with relief experienced within 10 to 14 days; other acute psychiatric syndromes such as severe excitement, e.g., in delirious mania, malignant catatonia, and neuroleptic malignant syndrome, may require ECT as a firstline treatment.

\section{Efficiency of remission, association with other therapies, and comparison between techniques}

Several trials have investigated remission as a parameter of efficiency of ECT use in adolescents. A study comparing patients who accepted ECT with those who refused this treatment showed that the first group improved significantly compared to the second [19]. The patients treated with ECT also had a shorter mean duration of hospital stay (73.8 vs. 176 days) [27]. In ten adolescents with primary, endogenous, psychotic depression who were resistant to antidepressant pharmacotherapy, ECT resulted in $60 \%$ of complete remission and $40 \%$ of partial remission after 1 month post-ECT [10].

In a cohort study with a sample that included adolescents, remission rates after treatment with ECT was equal for both adolescents and adults (58\% of remission). The difference between the two studied groups was that most adolescents had psychotic syndromes, 
Table 2 Electroconvulsive therapy use in adolescents: main findings

\begin{tabular}{|c|c|c|c|}
\hline Authors & $\begin{array}{l}\text { Publication } \\
\text { year }\end{array}$ & Journal & Main findings \\
\hline \multicolumn{4}{|c|}{ Indications for ECT use in adolescents } \\
\hline Wachtel et al. [6] & 2011 & Medical Hypotheses & $\begin{array}{l}\text { The use of ECT in children and adolescents is appropriate for } \\
\text { specific clinical indications and urge removal of impediments } \\
\text { to ECT access in this population }\end{array}$ \\
\hline Baeza et al. [7] & 2010 & $\begin{array}{c}\text { Journal of Child } \\
\text { and Adolescent } \\
\text { Psychopharmacology }\end{array}$ & $\begin{array}{l}\text { ECT is a safe and effective treatment for schizophrenia } \\
\text { spectrum disorders in adolescent patients }\end{array}$ \\
\hline Consoli et al. [14] & 2010 & Journal of ECT & $\begin{array}{l}\text { Electroconvulsive therapy is the effective treatment for } \\
\text { catatonia after high-dose benzodiazepine trials in youths }\end{array}$ \\
\hline Hazell [1] & 2009 & Clinical Evidence & $\begin{array}{l}\text { Electroconvulsive therapy is indicated for a severely obtunded } \\
\text { child or adolescent with depression who may, for example, have } \\
\text { prolonged psychotic symptoms, and fails to hydrate or maintain } \\
\text { caloric intake }\end{array}$ \\
\hline Baghai and Moller [16] & 2008 & $\begin{array}{l}\text { Dialogues in Clinical } \\
\text { Neuroscience }\end{array}$ & $\begin{array}{l}\text { The safety and tolerability of ECT have been enhanced by the } \\
\text { use of modified stimulation techniques and by the progress of } \\
\text { modern anesthesia, representing a safe treatment that can be offered } \\
\text { to all patients, especially after medication failure }\end{array}$ \\
\hline Stein et al. [24] & 2006 & $\begin{array}{l}\text { Child \& Adolescent } \\
\text { Psychiatric Clinics of } \\
\text { North America }\end{array}$ & $\begin{array}{c}\text { ECT is an effective therapy for severe and resistant depression, } \\
\text { with relatively minimal adverse effects }\end{array}$ \\
\hline Ghaziuddin et al. [27] & 2004 & $\begin{array}{l}\text { Journal of the American } \\
\text { Academy of Child and } \\
\text { Adolescent Psychiatry }\end{array}$ & $\begin{array}{l}\text { Eligible adolescents for ECT must meet three criteria: diagnosis } \\
\text { (severe, persistent major depression or mania, with or without } \\
\text { psychosis, schizoaffective disorder, schizophrenia, and others), } \\
\text { severity of symptoms, and lack of treatment response }\end{array}$ \\
\hline \multicolumn{4}{|c|}{ Electroconvulsive therapy: treatment parameters } \\
\hline Shoirah and Hamoda [13] & 2011 & $\begin{array}{l}\text { Expert Review of } \\
\text { Neurotherapeutics }\end{array}$ & $\begin{array}{c}\text { Although bilateral electrode placement may be more effective } \\
\text { than unilateral placement for manic patients, unilateral electrode } \\
\text { placement has been found to have equivalent results for } \\
\text { other indications }\end{array}$ \\
\hline Baeza et al. [7] & 2010 & $\begin{array}{l}\text { Journal of Child } \\
\text { and Adolescent } \\
\text { Psychopharmacology }\end{array}$ & $\begin{array}{c}\text { The mean duration of electroencephalogram seizures was } \\
43.9 \pm 16.9 \mathrm{~s} \text { (range, } 20 \text { to } 93 \text { ), with significant differences } \\
\text { between males and females }\end{array}$ \\
\hline Antunes et al. [15] & 2009 & Revista Brasileira de Psiquiatria & $\begin{array}{c}\text { Studies show that high-dose unilateral ECT (UL-ECT) has } \\
\text { an equivalent efficacy to bifrontotemporal ECT; however, } \\
\text { low-dose UL-ECT has lower efficacy }\end{array}$ \\
\hline
\end{tabular}

\section{Efficiency of ECT, associations with other therapies and comparison between techniques}

\begin{tabular}{|c|c|c|c|}
\hline Garg et al. [12] & 2011 & $\begin{array}{l}\text { Indian Journal of } \\
\text { Medical Research }\end{array}$ & $\begin{array}{l}\text { Patients with treatment-resistant schizophrenia treated } \\
\text { with ECT had an improvement in quality of life. All aspects of } \\
\text { quality of life got better, except the social relations }\end{array}$ \\
\hline Lévy-Rueff et al. [18] & 2008 & Psychiatry Research & $\begin{array}{l}\text { Part of a clinical cohort was composed by adolescents. } \\
\text { Maintenance ECT in association with pharmacological treatment } \\
\text { presented good outcomes for refractory schizophrenia }\end{array}$ \\
\hline Bloch et al. [29] & 2001 & $\begin{array}{l}\text { Journal of the American } \\
\text { Academy of Child and } \\
\text { Adolescent Psychiatry }\end{array}$ & $\begin{array}{c}\text { ECT was equally effective in adolescents and adults (58\% of remission), } \\
\text { but most of adolescents presented psychotic syndromes, instead } \\
\text { of affective disorders in adults }\end{array}$ \\
\hline Strober et al. [10] & 1998 & Biological Psychiatry & $\begin{array}{c}\text { Adolescents aged } 13 \text { to } 17 \text { years with bipolar depression or major } \\
\text { depressive disorder presented } 60 \% \text { of total and } 40 \% \text { of partial } \\
\text { remission in a month follow-up }\end{array}$ \\
\hline Kutcher and Robertson [34] & 1995 & $\begin{array}{l}\text { Journal of Child } \\
\text { and Adolescent } \\
\text { Psychopharmacology }\end{array}$ & $\begin{array}{c}\text { Patients who accepted ECT improved significantly compared to } \\
\text { those who refused. The mean duration of hospital stay was reduced } \\
\text { from } 176 \text { to } 73.8 \text { days }\end{array}$ \\
\hline Schneekloth et al. [37] & 1993 & Convulsive Therapy & $\begin{array}{l}\text { Retrospective study with a } 65 \% \text { response rate among } \\
\text { adolescents between } 13 \text { and } 18 \text { years old }\end{array}$ \\
\hline Paillère-Martinot et al. [39] & 1990 & Encephale & $\begin{array}{c}\text { Patients aged } 15 \text { to } 19 \text { years with different diagnoses achieved } \\
88 \% \text { of response rate after typical ECT application }\end{array}$ \\
\hline
\end{tabular}


Table 2 Electroconvulsive therapy use in adolescents: main findings (Continued)

\begin{tabular}{|c|c|c|c|}
\hline \multicolumn{4}{|c|}{ Side effects, risks, and complications of ECT for adolescents } \\
\hline Feliu et al. [17] & 2008 & $\begin{array}{l}\text { Neuropsychiatric Disease } \\
\text { and Treatment }\end{array}$ & $\begin{array}{c}\text { Relatively immediate and significant decreases in multiple areas } \\
\text { of memory following ECT, compared with pre-ECT levels of } \\
\text { functioning, including verbal memory for word lists, prose passages, } \\
\text { and visual memory of geometric designs }\end{array}$ \\
\hline Datka et al. [21] & 2007 & Klinika Psychiatrii CM UJ. & $\begin{array}{l}\text { One day after first ECT, patient's working memory was slightly impaired } \\
\text { ECT treatment affects working memory function only temporally }\end{array}$ \\
\hline Prakash et al. [22] & 2006 & Journal of ECT & $\begin{array}{l}\text { ECT presents cognitive side effects especially in recent memory. } \\
\text { The post-ECT recovery of various components of cognition was more } \\
\text { rapid in patients using donepezil and compared with placebo }\end{array}$ \\
\hline Cohen et al. [31] & 2000 & $\begin{array}{l}\text { The American } \\
\text { Journal of Psychiatry }\end{array}$ & $\begin{array}{c}\text { After a 3.5-year follow-up, patients who received ECT presented } \\
\text { similar memory functions to those of psychiatric controls. Poorer } \\
\text { cognitive performance is related with greater psychopathology, } \\
\text { not with the treatment }\end{array}$ \\
\hline Ghazziudin et al. [32] & 1999 & $\begin{array}{l}\text { Journal of Child } \\
\text { and Adolescent } \\
\text { Psychopharmacology }\end{array}$ & $\begin{array}{l}\text { Comparison with pre-ECT and post-ECT tests resulted in significant } \\
\text { impairments of concentration and attention, verbal and visual } \\
\text { delayed recall, and verbal fluency. Second stage of post-ECT tests } \\
\text { (mean, } 8.5 \text { months after ECT) showed complete recovery and } \\
\text { return to pre-ECT functioning }\end{array}$ \\
\hline
\end{tabular}

while adults had mainly affective disorders [35]. Maintenance ECT in association with pharmacological treatment presented good outcomes for refractory schizophrenia. ECT sessions in a group with drug-resistant schizophrenia resulted in an improvement in quality of life [27,32].

\section{Side effects, risks, and complications of ECT use}

In 1990, the APA Task Force on ECT cited no absolute contraindications to ECT [38]. Although some studies claim that even patients with severe cardiovascular conditions or neurological diseases may benefit from this therapy, guidelines still consider that more studies are needed to allow ECT use in such medical conditions $[24,25]$. Central nervous system tumors with high levels of cerebrospinal fluid, active pneumonia, and recent myocardial infarction are commonly considered relative contraindications in adolescents [39].

After an ECT session, patients must have their vital signs monitored for 1 to $2 \mathrm{~h}$. Delayed seizures are infrequent but can occur until $48 \mathrm{~h}$ after the procedure, representing a reason for monitoring patients in this period [37].

Tardive or prolonged seizures and memory impairment are adverse effects commonly associated to electroconvulsive therapy [39]. The health care team must be attentive to potential harmful effects of general anesthesia [31]. Headache, nausea and vomiting, agitation, and mental confusion are often reported as the most common adverse effects of ECT [14].

\section{Limitations of the retrieved studies}

Finally, it is important to highlight the methodological characteristics of the studies described in the present review, as methodological differences hamper the comparability and generalization of the results. The small samples with which most studies dealt with $[7,12,17,18,21,29,31,34]$, although probably caused by ethical barriers concerning experimental studies involving adolescents, reinforce the importance of assessing the consistency of the results found.

There were also other methodological limitations, such as the absence of control groups [7,30]. Although authors claim that these peculiarities do not affect the results, the generalization and reproducibility of findings may be impaired.

\section{Conclusions}

The common-sense knowledge that ECT is a risky practice makes it the most controversial and polemic treatment approach in psychiatry. However, even after the development of psychopharmacology in the 1950s, ECT maintains its relevance for psychiatry. Nowadays, ECT is still considered a highly efficient option for treatment of several psychiatric disorders, achieving high rates of remission, with few and relatively benign adverse effects.

Research on the use of ECT in adolescents can be considered recent, since the first studies date from the 1980s. Despite of that, ECT is the treatment of choice depending on diagnosis, severity of symptoms, and lack of response to psychopharmacotherapy. The majority of the studies in the scientific literature show the efficiency of ECT use in adolescents and consider this approach more efficient than psychopharmacotherapy isolated.

If ECT is performed in agreement with the guidelines, risks are relatively low. In addition, an experienced staff and adequate physical conditions can minimize the risk of complications. Taking this into account, an important area that requires further research is the development of programs that successfully prepare health care professionals to deal with ECT in the clinical ambience, being 
able to adequately conduct ECT procedures so as to stop the deleterious effects of the psychopathologies.

\section{Competing interests}

The authors declare that they have no competing interests.

\section{Authors' contributions}

MLRN, AOAR, NNRL, VBN, JCA, and CACV conceived of the study and participated in its design and coordination. JACP, MMM, SAT, JGJ, FTCJ, and DDMG drafted the manuscript. FTCJ, DDMG, AQB, JSC, and MA revised the manuscript. MLRN, AQB, JSC, and MA revised it critically for important intellectual content. All authors read and approved the final manuscript.

\section{Author details}

${ }^{1}$ Health Sciences Postgraduate Program, Faculty of Medicine, ABC Foundation, Santo André, São Paulo 09060-650, Brazil. ${ }^{2}$ Research Group CNPq/UFC: Information Technology, Communication, Narrativity, Society and Plural Identities, Federal University of Ceará (UFC), Juazeiro do Norte, Ceará 63.048-060, Brazil. ${ }^{3}$ Federal University of Campina Grande (UFCG), Cajazeiras, Paraíba 58900-000, Brazil. ${ }^{4}$ Neuropsychiatry and Behavioral Sciences Postgraduate Program, Federal University of Pernambuco (UFPE), Recife, Pernambuco 50.670-420, Brazil. ${ }^{5}$ Faculty of Medicine, Federal University of Ceará (UFC), Barbalha, Ceará 63180-000, Brazil. ${ }^{6}$ Public Health Faculty, University of São Paulo (USP), São Paulo 01246-904, Brazil.

Received: 26 December 2012 Accepted: 21 May 2013

Published: 30 May 2013

\section{References}

1. Hazell P: Depression in children and adolescents. Clin Evid (online) 2009, 2009.

2. Rolim-Neto ML, Silva TN, Assunção-Filho JKM, Carvalho RS, Teixeira SA, Lima NNR, Pedroso D, Cartaxo JS, Duarte Júnior JA, Demarzo MMP, Reis AAO: Childhood depression and psychocognitive development: description of causality relationships. Rev Bras Cresc Desenvolv Hum 2011, 21(3):894-898.

3. Baran B, Bitter I, Ungvári GS, Nagy Z, Gazdag G: The birth of biological therapy in Hungary: the story of László Meduna's first patient receiving convulsive therapy. Psychiatr Hung 2008, 23(5):366-375.

4. Meduna L: Autobiography. Convuls Ther 1985, 1:43-57; 121-135.

5. Baran B, Bitter I, Ungvari GS, Gazdag G: The birth of convulsive therapy revisited: a reappraisal of László Meduna's first cohort of patients. $J$ Affect Disord 2012, 136(3):1179-1182.

6. Wachtel LE, Dhossche DM, Kellner $\mathrm{CH}$ : When is electroconvulsive therapy appropriate for children and adolescents? Med Hypotheses 2011, 76(3):395-399.

7. Baeza I, Flamarique I, Garrido JM, Horga G, Pons A, Bernardo M, Morer A, Lázaro ML, Castro-Fornieles J: Clinical experience using electroconvulsive therapy in adolescents with schizophrenia spectrum disorders. J Child Adolesc Psychopharmacol 2010, 20(3):205-209.

8. Conselho Federal de Medicina (Brazilian Federal Council of Medicine): Resolução CFM No 1640/2002. Dispõe sobre a eletroconvulsoterapia e dá outras providências. Brasília: CFM; 2002

9. Moher D, Liberati A, Tetzlaff I, Altman DG: Preferred reporting items for systematic reviews and meta-analyses: the PRISMA statement. PLOS Med 2009, 6(7):e10097.

10. Strober M, Rao U, DeAntonio M, Liston E, Amaya-Jackson M, State L, Latz S: Effects of electroconvulsive therapy in adolescents with severe endogenous depression resistant to pharmacotherapy. Biol Psychiatry 1998, 43:335-338.

11. Gedge L, Beaudoin A, Lazowski L, Toit R, Jokic R, Milev R: Effects of electroconvulsive therapy and repetitive transcranial magnetic stimulation on serum brain-derived neurotrophic factor levels in patients with depression. Front Psychiatry 2012, 3:12.

12. Garg R, Chavan BS, Arun P: Quality of life after electroconvulsive therapy in persons with treatment resistant schizophrenia. Indian J Med Res 2011 133(6):641-644.

13. Shoirah $\mathrm{H}$, Hamoda HM: Electroconvulsive therapy in children and adolescents. Expert Rev Neurother 2011, 11(1):127-137.

14. Consoli A, Benmiloud M, Wachtel L, Dhossche D, Cohen D, Bonnot O: Electroconvulsive therapy in adolescents with the catatonia syndrome: efficacy and ethics. J ECT 2010, 26(4):259-265.

15. Antunes PB, Rosa MA, Belmonte-de-Abreu PS, Lobato MIR, Fleck MP: Electroconvulsive therapy in major depression: current aspects. Rev Bras Psiquiatr 2009, 31(Suppl. 1):S26-S33.
16. Baghai TC, Moller HJ: Electroconvulsive therapy and its different indications. Dialogues Clin Neurosci 2008, 10(1):105-117.

17. Feliu M, Edwards CL, Sudhakar S, McDougald C, Raynor R, Johnson S: Neuropsychological effects and attitudes in patients following electroconvulsive therapy. Neuropsychiatr Dis Treat 2008, 4(3):613-617.

18. Lévy-Rueff M, Jurgens A, Lôo H, Olié JP, Amado I: Maintenance electroconvulsive therapy and treatment of refractory schizophrenia. Encéphale 2008, 34(5):526-533.

19. Arshad M, Arham AZ, Arif M, Bashir A, Bokutz M, Choudhary MM: Awareness and perceptions of electroconvulsive therapy among psychiatric patients: a cross-sectional survey from teaching hospitals in Karachi, Pakistan. BMC Psychiatry 2007, 7:27.

20. Blaj A, Worrall A, Chaplin R: Electroconvulsive therapy: the practice and training needs of referring psychiatrists in the United Kingdom and Republic of Ireland. J ECT 2007, 23(2):78-81.

21. Datka W, Siwek M, Dudek D, Maczka G, Zieba A: Working memory disturbances in patients with major depression after ECT treatment. Psychiatr Pol 2007, 41(3):339-349.

22. Prakash J, Kotwal A, Prabhu H: Therapeutic and prophylactic utility of the memory-enhancing drug donepezil hydrochloride on cognition of patients undergoing electroconvulsive therapy: a randomized controlled trial. J ECT 2006, 22:163-168.

23. Salleh MA, Papakostas I, Zervas I, Christodoulou G: Eletroconvulsoterapia: critérios e recomendações da Associação Mundial de Psiquiatria. Rev Psiquiatr Clin 2006, 33(5):262-267.

24. Stein D, Weizman A, Bloch Y: Electroconvulsive therapy and transcranial magnetic stimulation: can they be considered valid modalities in the treatment of pediatric mood disorders? Child Adolesc Psychiatr Clin N Am 2006, 15(4):1035-1056.

25. Zaw FK: ECT and the youth. Int Rev Neurobiol 2006, 72:207-231.

26. Sienaert P, De-Becker T, Vansteeldant K, Demyttenaere K, Peuskens J: Patient satisfaction after electroconvulsive therapy. J ECT 2005, 21(4):227-231.

27. Ghaziuddin N, Kutcher SP, Knapp P, Bernet W, Arnold V, Beitchman J, Benson RS, Bukstein O, Kinlan J, McClellan J, Rue D, Shaw JA, Stock S, Kroeger Ptakowski K, Work Group on Quality Issues, AACAP: Practice parameter for use of electroconvulsive therapy with adolescents. J Am Acad Child Adolesc Psychiatry 2004, 43(12):1521-1539.

28. Segal J, Szabo CP, Toit J: Child and adolescent electroconvulsive therapy: a case report. World J Biol Psychiatry 2004, 5(4):221-229.

29. Bloch Y, Levcovitch Y, Bloch AM, Mendlovic S, Ratzoni G: Electroconvulsive therapy in adolescents: similarities to and differences from adults. J Am Acad Child Adolesc Psychiatry 2001, 40(11):1332-1336.

30. Daly JJ, Prudic J, Devanand DP, Nobler MS, Lisanby SH, Peyser S, Roose SP, Sackeim HA: ECT in bipolar and unipolar depression: differences in speed of response. Bipolar Disord 2001, 3(2):95-104.

31. Cohen D, Taieb O, Flament M: Absence of cognitive impairment at long-term follow-up in adolescents treated with ECT for severe mood disorders. Am J Psychiatry 2000, 157:460-462.

32. Ghaziuddin N, De-Quardo JR, Ghaziuddin M, King CA: Electroconvulsive therapy of a bipolar adolescent post-craniotomy for brain stem astrocytoma. J Child Adolesc Psychopharmacol 1999, 9:63-69.

33. Thuppal M, Fink M: Electroconvulsive therapy and mental retardation. J ECT 1999, 15:140-149.

34. Kutcher S, Robertson HA: Electroconvulsive therapy in treatment-resistant bipolar youth. J Child Adolesc Psychopharmacol 1995, 5:167-175.

35. Calev A: Neuropsychology and ECT: past and future research trends. Psychofarmacol Bull 1994, 30:461-469.

36. Parmar R: Attitudes of child psychiatrists to electroconvulsive therapy. Psychiatr Bull 1993, 17:12-13.

37. Schneekloth TD, Rummans TA, Logan KM: Electroconvulsive therapy in adolescents. Convuls Ther 1993, 9:158-166.

38. American Psychiatry Association Task Force on Electroconvulsive Therapy: The practice of ECT: recommendations for treatment, training and privileging. Convuls Ther 1990, 6:85-120.

39. Paillère-Martinot ML, Zivi A, Basquin M: Utilisation de I'ECT chez l'adolescent. Encéphale 1990, 16:399-404.

doi:10.1186/1744-859X-12-17

Cite this article as: Lima et al:: Electroconvulsive therapy use in adolescents: a systematic review. Annals of General Psychiatry 2013 12:17. 